\title{
SOME SPECIFIC MICROBIOLOGICAL PARAMETERS AND PREVALENCE OF SALMONELLA SPP. IN RETAIL CHICKEN MEAT FROM ERZURUM PROVINCE, TURKEY AND CHARACTERIZATION OF ANTIBIOTIC RESISTANCE OF ISOLATES
}

\author{
ALGUNS PARÂMETROS MICROBIOLÓGICOS ESPECÍFICOS E PREVALÊNCIA DE \\ SalmonellA spp. CORTES DE CARNE DE FRANGO DA PROVÍNCIA DE ERZURUM, \\ TURQUIA E CARACTERIZAÇÃO DA RESISTÊNCIA AOS ANTIBIÓTICOS DE \\ ISOLADOS
}

\author{
Alper BARAN'; Ahmet ERDOĞAN²; Arzu Kavaz³ ${ }^{3}$ Mehmet Cemal Adigüzel ${ }^{4}$ \\ 1. Assistant Professor Doctor, Atatürk University, Erzurum Vocational School, Department of Food Quality Control and Analysis, \\ 25240 Erzurum, Turkey. alper.baran@atauni.edu.tr; 2. Professor Doctor, Atatürk University, Faculty of Agriculture, Department of \\ Food Engineering, 25240 Erzurum, Turkey; 3. Associate Doctor, Atatürk University, Erzurum Vocational School, Department of Food \\ Technology, 25240 Erzurum, Turkey; 4. Assistant Professor Doctor, Atatürk University, Faculty of Veterinary, Department of \\ Microbiology, 25240 Erzurum, Turkey
}

\begin{abstract}
Specific microbiological parameters and the presence of Salmonella spp. were investigated in 72 chicken meat samples (36 wings and 36 drumsticks) collected from markets and butcher shops. The specific microbiological parameters were determined using a conventional cultural method and the presence of Salmonella spp. in chicken samples was determined using conventional and immunomagnetic separation (IMS)-polymerase chain reaction (PCR) methods. In addition, antimicrobial susceptibility of the isolates was revealed using the Kirby-Bauer disc diffusion method. The results indicated that 30 of the 72 samples were positive for Salmonella spp. by the conventional method, and 42 of the 72 were positive by the IMS-PCR method. However, 30 of the 72 samples were positive for Salmonella spp. by both methods. The Salmonella spp. isolates were confirmed by the VITEK2 Compact System and PCR. The susceptibilities of the isolates against 10 antibiotics were determined. The results indicated that isolates (27/30) showed the highest susceptibility to gentamycin $(90.00 \%)$, while the highest resistance was to nalidixic acid and tetracycline at the 100 and 93.34\% levels, respectively. These results indicate a high prevalence of Salmonella spp. in poultry meat from Erzurum city, Turkey, and the antimicrobial resistance profile of these isolates should be considered for public health. The results also show that the IMS-PCR technique was superior to the conventional method for detecting Salmonella in poultry meat.
\end{abstract}

KEYWORDS: Chicken meat. Salmonella. IMS. PCR. Antimicrobial.

\section{INTRODUCTION}

Chicken is one of the most popular food products worldwide, because of nutritional, sensorial and economic factors. Chicken is widely consumed in homes and fast-food establishments, but can become contaminated during processing. The contamination of poultry products with Salmonella and other microorganisms is due to unhygienic conditions during the production, processing, distribution, marketing and preparation stages (DOOKERAN et al., 2012).

The genus Salmonella includes short rodshaped, facultative anaerobe, Gram-negative bacteria. Warm-blooded animals and humans are natural hosts for Salmonella spp. Detecting Salmonella spp. during production and before consumption is important to prevent food-borne salmonellosis. A Salmonella infection in humans is usually caused by consuming undercooked meat or other cross-contaminated foods, such as vegetables, milk and eggs (HASSANEIN et al., 2011). According to a report published by the Centres for Disease Control and Prevention (CDC), it is estimated that about 1.2 million people in the US have been exposed to Salmonella infections, and that an average of 23.000 hospitalisations and 450 deaths occur from these infections. The prevalence rates of Salmonella spp. in chicken meat sold in Turkey are $34-68.75 \%$. Not only in Turkey, but in most developing countries, the absence of an epidemiological surveillance system for salmonellosis cases makes it difficult to effectively assess prevalence (KÄFERSTEIN, 2003). However, 
1.993 cases of gastroenteritis in Turkey were due to Salmonella spp. in 2008, and the number increased to 2.307 in 2011, according to unpublished data from the Department of Communicable Diseases of the Turkish Public Health Institution (THSK, 2015).

Salmonellosis is one of the most important zoonotic bacterial food-borne infections worldwide. Salmonella causes severe illness in infants, elderly humans and immunocompromised patients. Generally, Salmonella infections are related to infected animals' faeces or food products of animal origin. Chicken and other poultry meat and eggs are the most significant sources of Salmonella compared with other food products. Salmonella causes gastrointestinal illness, substantial morbidity and economic burden worldwide. The clinical symptoms of salmonellosis are characterised by fever, diarrhoea, nausea, vomiting, abdominal pain, headache and occasional constipation 12-72 $\mathrm{h}$ after consuming contaminated food (VOSE et al., 2011).

Increased public awareness about foodborne illness has necessitated the development of rapid, sensitive and specific techniques for detecting these food-borne pathogens. Isolation and identification of Salmonella from food samples requires approximately 7 days using traditional cultural techniques. In recent years, more rapid and sensitive methods have been developed to detect and identify Salmonella in chicken meat, including immunoassays, electrical techniques and nucleic acid analyses (BENNETT et al., 1998). Among these, immunomagnetic separation (IMS) and polymerase chain reaction (PCR) have been accepted as a potential approach for detecting these pathogens (YANG et al., 2010).

IMS has been successfully used to separate and concentrate target microorganisms from food samples using magnetic beads coated with specific antibodies to a target microorganism. This method is a quite rapid, specific and technically simple approach, as the target organism is captured by the magnetic particles and removed from the media by a applying a magnetic field (LYNCH et al., 2004). Finally, the microorganism is removed from the food debris and other competing microorganisms and is subjected to an enzyme linked immunosorbent assay or PCR analysis (HAGREN et al., 2008 ; LYNCH et al., 2004).

PCR detects pathogens from foods within a few hours and is a rapid alternative method to detect Salmonella (MOGANEDI et al., 2007). Although PCR is a sensitive, rapid technique, it can be inhibited by several factors, including food components, urine and bile salts; thus, different approaches, such as IMS, have been used to remove these substances prior to PCR (SCHEU et al., 1998). IMS isolates Salmonella from other microbes and facilitates removal of PCR inhibitors of different sizes. The combination of different rapid methods for separating and concentrating specific bacteria facilitates direct detection of pathogens in foods. The combination of IMS and PCR (IMS-PCR) is considered quite accurate and rapid for isolating pathogens (TABAN; AYTAC, 2009).

The invA gene region is located in the Salmonella pathogenicity $1 \mathrm{~B}$ island and is necessary for Salmonella to invade epithelial cells (Lei et al., 2015). This genomic region, which is found in almost all Salmonella serovars, is a powerful target for detecting Salmonella (JEONG et al., 2011).

Antimicrobial resistance has increased among food-borne pathogenic microorganisms during recent decades (TEUBER, 2001). This increase is caused by irregular use of antimicrobials in food-producing animals and the random use of antibiotics by humans (BYWATER, 2004). Antibiotic-resistant Salmonella-related data are needed to assess the potential effect of resistant isolates (three or more antibiotic-resistant strains) isolated from raw chicken meat on public health (NAIR et al., 2018).

The aim of this study was to determine the general microbiological quality characteristics and presence of Salmonella spp. in different chicken meat samples obtained from supermarkets and butcher shops. In addition, this study compared and evaluated a conventional method with IMS-PCR analysis for detecting Salmonella spp. in chicken meat samples, and determined the antibiotic susceptibility and resistance of Salmonella spp. isolated from samples against 10 different antimicrobial agents.

\section{MATERIAL AND METHODS}

\section{Material}

In total, 72 packed chicken meat samples were collected from 19 different local markets and retail stores, in Erzurum city, Turkey during the May-December 2016. All samples were transferred to the laboratory under cold chain within one hour and microbiological analyses were carried out on the same day.

\section{Microbiological Analysis}

Microbiological analysis were performed according to methods of Turkish Standard Institute number of 1069 standard (TSE, 2016). Ten $\mathrm{g}$ of chicken meat was weighed for each sample and transferred to sterile stomacher bag which contained 
$90 \mathrm{ml}$ of sterile Ringers (MERCK, 115525) 1/4 solution and mixture was homogenized by a stomacher blender (IUL Instruments, Barcelona, Spain) for $90 \mathrm{~s}$. Then a series of 10-fold dilutions was prepared in tubes and each of the diluted sample $(0.1 \mathrm{~mL})$ was plated on proper growth media except for total coliforms (coliforms were sown by pouring method). Total aerobic mesophilic bacteria were enumerated on Plate Count Agar (PCA) (Merck, 105463), at $35 \pm 1{ }^{\circ} \mathrm{C}$ for $48-72 \mathrm{~h}$; total coliforms were counted on Violet Red Bile (VRB) Agar (Oxoid, CM0107B) at $35 \pm 1{ }^{\circ} \mathrm{C}$ for $18-24 \mathrm{~h}$; Enterococcus was determined on Kanamycin Aesculin Azide (KAA) Agar (Oxoid, CM0591) at $35 \pm 1{ }^{\circ} \mathrm{C}$ for $24 \mathrm{~h}$; for Staphylococcus aureus enumeration, Baird Parker Agar (BPA) (Merck, 1.05406) that supplemented with egg yolk telluride was used and incubated at $37 \pm 1^{\circ} \mathrm{C}$ for 24 to $48 \mathrm{~h}$. Micrococcus/Staphylococcus was counted on Mannitol Salt Agar (MSA) (Oxoid, CM0085) at $30 \pm 1{ }^{\circ} \mathrm{C}$ for $24 \mathrm{~h}$; Pseudomonas was determined on Pseudomonas Selective Agar (Merck, 1.07620) supplemented with CFC (Merck, 1.07627) at $25^{\circ} \mathrm{C}$ for $48 \mathrm{~h}$; yeast and moulds were counted on Rose Bengal Chloramphenicol (RBC) Agar (Merck, $1.00467)$ at $25^{\circ} \mathrm{C}$ for $5-7 \mathrm{~d}$.

\section{Bacterial Strain}

Positive control used in PCR assay was obtained from Turkey Public Health Institution Microbiology Reference Laboratories (Salmonella typhimurium RSSK 95091).

\section{Isolation and Identification of Salmonella spp. Conventional Method}

Isolation and identification of Salmonella spp. was performed according to method of ISO (2002). Briefly, $25 \mathrm{~g}$ of meat sample was transferred to filtered stomacher bags containing $225 \mathrm{~mL}$ of sterile buffered peptone water (Merck, 107228) and homogenized with masticator (Neutec Masticator, Neutec Group, Inc., Farmingdale, NY) for $90 \mathrm{~s}$. Homogenized samples were incubated for preenrichment during $24 \mathrm{~h}$. Then, $1 \mathrm{~mL}$ was transferred to tube containing Muller-Kauffmann tetrathionate/novabiocin broth (MKTTn) (Oxoid, CM1048) supplemented with novobiocin (Oxoid, SR0181) in $10 \mathrm{~mL}$ volume and $0.1 \mathrm{~mL}$ of preenriched solution was transferred to tube containing Rappaport-Vassiliadis (RV) medium (Merck, $1.07700)$ in $10 \mathrm{~mL}$ volume. For selective enrichment, the tubes with RV were incubated at $41.5^{\circ} \mathrm{C}$ for $24 \mathrm{~h}$ and inoculated tubes with MKTTn were incubated for $37^{\circ} \mathrm{C}$ for $24 \mathrm{~h}$. Following the incubation, the enriched samples were streaked onto
Xylose Lysine Tergitol-4 (XLT-4) Agar (Oxoid, CM1061) supplemented with tergitol (Oxoid, SR0237) and Xylose Lysine Deoxycholate (XLD) Agar (Merck 1.05287) and incubated at $37^{\circ} \mathrm{C}$ overnight. The colonies with a black centre with pinky-reddish periphery on XLD agar and black or black-centred with a yellow periphery on XLT4 Agar were accepted as suspicious for Salmonella. The suspicious colonies of Salmonella spp. were selected and identified by Triple Sugar Iron Agar (TSIA) (Oxoid, CM0277B), Lysine Iron Agar (LIA) (Oxoid, CM0381) and urea broth (Merck, 1.08483). Following the incubation at $37^{\circ} \mathrm{C}$ for $24 \mathrm{~h}$, typical reaction on TSIA (alkaline slant, acid butt, positive $\mathrm{H}_{2} \mathrm{~S}$ and positive/negative gas) and LIA (alkaline slant, alkaline butt, positive $\mathrm{H}_{2} \mathrm{~S}$ ) and urea negative cultures were evaluated as suspicious for Salmonella. The other biochemical tests were performed by using GN Cards (BioMérieux, Inc., Craponne, France) including 64 different test substrates on VITEK 2 Compact system (BioMérieux) for verifying the isolates. For this purpose, the isolates were incubated at $37^{\circ} \mathrm{C}$ for 24 hours on blood agar. A sufficient number of colonies from pure culture were suspended in a polystyrene tube containing $3.0 \mathrm{~mL}$ of sterile saline solution $(0.45 \%, \mathrm{pH} 4.5)$. The McFarland turbidity of solution was adjusted to 0.5 using a turbidity meter. Then, the suspension was loaded on the GN cards. Identification of presumptive Salmonella spp. isolates were performed on VITEK2 Compact System (BioMérieux, Marcy l'Étoile, France) within $3 \mathrm{~h}$ using fluorescence reading of GN cards. VITEK2 Compact System Software identified the isolates as Salmonella spp. at the level of $97-99 \%$ probability.

\section{IMS Method}

Salmonella spp. were separated from preenriched samples by Dynabeads ${ }^{\circledR}$ anti-Salmonella (ThermoFischer Scientific, 71002) according to the manufacturer's instruction. Briefly, $20 \mu \mathrm{L}$ of Dynabeads $^{\circledR}$ anti-Salmonella was transferred into $1.5 \mathrm{~mL}$ of sterile eppendorfs. After, $1 \mathrm{~mL}$ preenriched samples were added to eppendorfs and incubated with gentle agitation for $10 \mathrm{~min}$. Then, a magnetic plate was placed on the MPC-S rack and recovery of the beads was performed for 3 minutes. The IMS beads-bacteria complex on the tube wall were washed with $1 \mathrm{~mL}$ wash buffer (PBS with $0.05 \%$ Tween-20) following the removal of the magnetic plate from the MPC-S rack. The washing process was repeated twice. 


\section{Post-IMS}

DNA extraction from the Dyne beadbacterial complex was performed by the boiling method. For this purpose, $100 \mu \mathrm{L}$ of Tris-EDTA buffer solution $(\mathrm{pH}, 8.0)$ containing dyne beadbacteria was boiled for $10 \mathrm{~min}$. At the end of the boiling, the samples were cooled on ice and centrifuged at $10.000 \mathrm{x} g$ for $15 \mathrm{sec}$. The supernatant was used template in PCR.

\section{PCR Method}

PCR primers (invAFW: 5'-ACA GTG CTC GTT TAC GAC CTG AAT-3'; invARV 5'-AGA CGA CTG GTA CTG ATC GAT AAT-3') were used to specifically amplify a 284-bp genomic fragment of the $i n v A$ gen, which is highly specific for Salmonella spp. for PCR assays of the isolates. The PCR amplifications were performed in a total volume of $15 \mu \mathrm{L}$ solution containing $2 \mu \mathrm{L}$ of template DNA, $1 \times$ PCR buffer (Sigma), $0.25 \mathrm{mM}$ $\mathrm{MgCl}_{2}$ (Sigma), $200 \mu \mathrm{M}$ (each) dNTP (Sigma), 10 pmol of each primer, $1.25 \mathrm{U}$ of Taq polymerase (Sigma). The PCR cycle condition was an initial denaturation at $95^{\circ} \mathrm{C}$ for $10 \mathrm{~min} ; 30$ cycles of $95^{\circ} \mathrm{C}$ $30 \mathrm{~s}, 55^{\circ} \mathrm{C} 30 \mathrm{~s}$ and $72^{\circ} \mathrm{C} 30 \mathrm{~s}$; and a final extension at $72^{\circ} \mathrm{C}$ for $5 \mathrm{~min}$. The amplified products were detected by electrophoresis in a $1 \%$ agarose gel in Tris/Borate/EDTA Buffer (TBE, pH 8.3) pre-stained with ethidium bromide under UV light using Gel Doc $^{\mathrm{TM}} \mathrm{XR}+$ Gel Documentation System (BioRad, USA).

\section{Antibiotic Susceptibility Test of Obtained Isolates}

The antimicrobial susceptibilities of the obtained isolates were determined by agar disk diffusion method proposed by Clinical \&
BARAN, A. et al.

Laboratory Standards Institute (CLSI, 2012). Then, isolates were spread onto petri dishes containing Nutrient agar and incubated for 18 hours at $35 \pm 1^{\circ} \mathrm{C}$. The colonies were diluted in $0.85 \%$ physiological saline and the turbidity of the inoculum was adjusted to $0.5 \mathrm{McF}$ arland standard. The suspension was then streaked onto surface of Müeller Hinton Agar in petri dish with a sterile swap. The following antibiotic discs: ampicillin (AMP, Oxoid CT003B), chloramphenicol (C, Oxoid CT013B), ciprofloxacin (CIP, Oxoid CT425B), gentamicin (CN, Oxoid CT024B), kanamycin (K, Oxoid CT026B), nalidixic acid (NA, Oxoid CT031B), streptomycin (S, Oxoid CT047B), sulfamethox/trimethoprim (SXT, Oxoid CT052B), tetracycline (TE, Oxoid CT054B) trimethoprim (W, Oxoid CT076B) were dispensed onto the inoculated surface within 15 minutes. Then the petri dishes were incubated in ambient air at $35^{\circ} \mathrm{C}$ for $18 \mathrm{~h}$. The nearest millimeter was measured with a ruler following the incubation. The results were interpreted according to the standards of Clinical \& Laboratory Standards Institute (CLSI Guidelines). Antibiotic susceptibility of isolates was evaluated as resistance, intermediate and sensitive (CLSI, 2012).

\section{Statistical Analysis}

Statistical analysis was performed using SPSS Software Programme (SPSS software, version 20). $P$ value of 0.05 or less was considered to indicate a statistically significant difference.

\section{RESULTS}

The general microbial counts $(\log \mathrm{cfu} / \mathrm{g})$ in the chicken meat samples collected from 19 retail markets are presented in Table 1.

Table 1. The general microbiological properties and presence of Salmonella spp. in chicken meat samples (log cfu/g).

\begin{tabular}{|c|c|c|c|c|c|c|c|c|}
\hline Sample ID & TAMB & Pseudomonads & $\begin{array}{c}\text { Mold and } \\
\text { yeast }\end{array}$ & Coliform & Enterococci & $\begin{array}{l}\text { Staph- } \\
\text { Microcci }\end{array}$ & $\begin{array}{c}\text { IMS- } \\
\text { PCR } \\
\text { Method }\end{array}$ & $\begin{array}{l}\text { Conventional } \\
\text { Method }\end{array}$ \\
\hline 1 & 7.28 & 6.09 & 5.90 & 4.55 & 2.28 & 4.40 & + & + \\
\hline 2 & 7.28 & 5.08 & 4.58 & 4.15 & $<2$ & 4.30 & + & - \\
\hline 3 & 4.48 & 3.00 & 2.23 & 2.00 & $<2$ & $<2$ & + & + \\
\hline 4 & 7.35 & 5.06 & 4.90 & 6.00 & 4.11 & 4.00 & + & - \\
\hline 5 & 5.00 & 4.32 & 0.82 & $<2$ & $<2$ & 4.00 & + & + \\
\hline 6 & 6.39 & 6.28 & 5.00 & 4.92 & 2.30 & 4.00 & - & - \\
\hline 7 & 6.36 & 4.21 & 1.27 & $<2$ & 2.48 & 3.11 & + & + \\
\hline 8 & 5.85 & 4.32 & 4.00 & 4.97 & 2.60 & 2.85 & - & - \\
\hline 9 & 7.30 & 3.90 & 3.30 & 5.32 & 3.48 & 4.85 & + & + \\
\hline 10 & 1.27 & $<2$ & $<2$ & 3.30 & $<2$ & $<2$ & + & + \\
\hline 11 & 7.00 & $<2$ & 4.31 & $<2$ & $<2$ & $<2$ & - & - \\
\hline 12 & 6.21 & $<2$ & $<2$ & 4.30 & 3.00 & $<2$ & - & - \\
\hline 13 & 4.00 & $<2$ & $<2$ & 3.48 & 2.30 & 3.35 & - & - \\
\hline 14 & 5.19 & 4.11 & 4.00 & 5.13 & 2.78 & 3.18 & - & - \\
\hline
\end{tabular}


Some specific microbiological...

BARAN, A. et al.

\begin{tabular}{|c|c|c|c|c|c|c|c|c|}
\hline 15 & 6.21 & 6.26 & 5.65 & $<2$ & $<2$ & $<2$ & + & - \\
\hline 16 & 6.23 & 2.22 & 5.74 & 4.09 & $<2$ & 5.65 & - & - \\
\hline 17 & 6.82 & 2.33 & 5.60 & 4.37 & 1.30 & 4.66 & - & - \\
\hline 18 & 6.35 & 5.74 & 4.90 & 4.34 & 1.78 & $<2$ & - & - \\
\hline 19 & 7.10 & 6.40 & 4.70 & 4.65 & 1.48 & $<2$ & - & - \\
\hline 20 & 6.72 & 5.67 & 5.00 & 5.60 & $<2$ & $<2$ & + & - \\
\hline 21 & 4.63 & 4.04 & 3.48 & 2.57 & $<2$ & 3.00 & + & - \\
\hline 22 & 6.03 & 3.56 & 3.78 & 3.06 & 1.78 & $<2$ & + & - \\
\hline 23 & 6.83 & 4.28 & 3.90 & 6.33 & 3.71 & 4.29 & + & - \\
\hline 24 & 6.01 & 2.00 & 3.23 & 4.27 & 3.28 & 3.76 & + & - \\
\hline 25 & 9.41 & 4.78 & 5.16 & 7.61 & $<2$ & 4.60 & + & + \\
\hline 26 & 10.05 & 4.30 & 5.48 & 6.52 & 3.70 & 4.30 & + & + \\
\hline 27 & 4.00 & $<2$ & $<2$ & $<2$ & $<2$ & 2.00 & - & - \\
\hline 28 & 4.00 & 2.00 & 3.00 & 3.70 & 3.18 & 2.48 & + & + \\
\hline 29 & 5.00 & 2.30 & $<2$ & 3.20 & 2.00 & 2.00 & + & - \\
\hline 30 & 7.95 & 3.65 & 4.20 & 4.32 & 2.70 & 2.30 & + & + \\
\hline 31 & 6.20 & 5.52 & 3.00 & 5.20 & 2.85 & $<2$ & + & + \\
\hline 32 & 6.28 & 5.30 & 4.00 & 4.62 & 2.78 & $<2$ & + & - \\
\hline 33 & 6.00 & 4.15 & 5.00 & 4.66 & 2.85 & 2.78 & + & + \\
\hline 34 & 7.48 & 5.88 & 4.88 & 5.40 & 3.66 & 4.08 & + & + \\
\hline 35 & 7.11 & 4.34 & 5.32 & 4.97 & 3.26 & 3.84 & - & - \\
\hline 36 & 4.48 & $<2$ & 3.00 & 3.00 & 2.00 & 2.30 & - & - \\
\hline 37 & 6.27 & 4.00 & 4.19 & 4.42 & 2.30 & 2.90 & - & - \\
\hline 38 & 4.62 & 3.95 & $<2$ & $<2$ & $<2$ & $<2$ & - & - \\
\hline 39 & 7.33 & 5.00 & 5.44 & 4.48 & 2.26 & 5.30 & + & + \\
\hline 40 & 7.00 & 5.04 & 5.20 & 4.24 & $<2$ & 3.00 & - & - \\
\hline 41 & 7.42 & 5.36 & 4.48 & 6.70 & 1.60 & 4.00 & + & - \\
\hline 42 & 5.00 & $<2$ & 2.36 & 4.00 & 1.74 & 4.00 & + & + \\
\hline 43 & 7.41 & 5.82 & 5.35 & 5.03 & 2.00 & 4.30 & + & + \\
\hline 44 & 6.33 & 4.62 & 5.15 & 3.00 & 3.20 & 3.30 & + & + \\
\hline 45 & 5.29 & 3.54 & 2.60 & 3.78 & 3.20 & 4.28 & - & - \\
\hline 46 & 6.72 & 3.30 & 3.00 & 4.66 & 4.15 & 4.72 & - & - \\
\hline 47 & 6.30 & 3.00 & 3.55 & 4.30 & $<2$ & 3.48 & + & + \\
\hline 48 & 7.22 & 4.48 & 4.88 & 5.64 & 3.95 & 4.30 & - & - \\
\hline 49 & 8.18 & 3.25 & 3.30 & 4.60 & 3.85 & $<2$ & + & + \\
\hline 50 & 7.72 & 4.91 & 4.48 & 6.08 & 5.60 & 2.95 & - & - \\
\hline 51 & 6.46 & 5.10 & 4.63 & 5.68 & 2.70 & 3.00 & - & - \\
\hline 52 & 6.10 & 4.23 & 4.48 & 2.72 & $<2$ & $<2$ & + & + \\
\hline 53 & 6.26 & 4.82 & 4.30 & 3.99 & 1.60 & 6.06 & + & + \\
\hline 54 & 7.02 & 5.25 & 5.18 & 2.90 & $<2$ & 3.90 & + & - \\
\hline 55 & 7.09 & 5.90 & 5.67 & 4.32 & 3.08 & $<2$ & + & - \\
\hline 56 & 7.18 & 5.03 & 5.20 & 5.37 & 2.40 & 3.48 & - & - \\
\hline 57 & 6.22 & 6.34 & 3.88 & 5.33 & 3.60 & 4.26 & + & + \\
\hline 58 & 5.82 & 2.64 & 5.48 & 4.35 & $<2$ & 4.99 & + & - \\
\hline 59 & 5.92 & 5.98 & 4.54 & 3.62 & $<2$ & $<2$ & - & - \\
\hline 60 & 7.11 & 3.68 & 3.36 & 5.66 & 3.88 & 4.38 & - & - \\
\hline 61 & 4.00 & 2.48 & 2.90 & 4.23 & 3.32 & 3.49 & - & - \\
\hline 62 & 9.52 & 7.23 & 5.20 & 6.76 & 0.00 & 4.30 & - & - \\
\hline 63 & 5.75 & 5.66 & 5.66 & $<2$ & 5.67 & 4.00 & - & - \\
\hline 64 & 7.23 & 5.26 & 4.77 & 5.60 & 3.36 & 3.76 & - & + \\
\hline 65 & 7.87 & 5.82 & 5.97 & $<2$ & 3.87 & 4.27 & - & + \\
\hline 66 & 7.16 & 3.90 & 4.95 & 6.20 & 4.03 & 4.51 & + & + \\
\hline 67 & 6.72 & 3.69 & 4.23 & 5.12 & 3.00 & 3.11 & + & + \\
\hline 68 & 5.70 & 5.20 & 5.30 & 5.75 & 3.65 & $<2$ & + & + \\
\hline 69 & 7.24 & 4.00 & 4.70 & 5.42 & 3.20 & $<2$ & + & + \\
\hline 70 & 4.88 & 4.16 & 4.00 & 4.00 & $<2$ & 3.87 & + & + \\
\hline 71 & 6.30 & 2.85 & 5.33 & 5.08 & 2.70 & 3.00 & - & - \\
\hline 72 & 5.59 & 4.13 & 4.34 & 5.29 & 3.23 & 3.71 & + & + \\
\hline
\end{tabular}


As shown in Table 1, the total aerobic mesophilic bacteria count (TAMB), Pseudomonas, yeast and moulds, coliform bacteria, Enterococcus and Staphylococcus/Micrococcus counts of the 72 chicken meat samples showed differences of 4.0010.05 , <10-7.23, <10-5.97, <10-7.61, <10-5.67 and $<10-6.06$, respectively.
Thirty of the $72(41.67 \%)$ chicken meat samples were positive for Salmonella spp. by the conventional method, whereas 42 of the 72 $(58.33 \%)$ samples were positive by the IMS-PCR method. Thirty of the $72(41.67 \%)$ samples were positive for Salmonella spp. by both methods (Table 2).

Table 2. The obtained Salmonella spp. results that were determined by conventional and IMS-PCR methods.

\begin{tabular}{lccc}
\hline & Conventional & IMS/PCR & Both methods \\
\hline $\mathrm{n} / \mathrm{N}$ & $30 / 72$ & $42 / 72$ & $30 / 72$ \\
$\%$ & 41.67 & 58.33 & 41.67 \\
\hline
\end{tabular}

The IMS-PCR technique was applied to the chicken meat samples collected from different markets and retail stores. The invA (284 bp) gene was prepared using the IMS-PCR technique. The invAFW: 5'-ACA GTG CTC GTT TAC GAC CTG AAT-3' and invARV 5'-AGA CGA CTG GTA CTG ATC GAT AAT-3' primers were used to specifically amplify a 284-bp genomic fragment of the invA gene. The PCR image is shown in Fig. 1. As shown in Fig. 1, lane 9 was the negative control and lane 8 was the positive control, whereas lanes 2 7 were the Salmonella spp. positive samples. Lane 1 was verified to be a Salmonella spp.-negative sample. All Salmonella spp. determined by the conventional method carried the invA gene region.

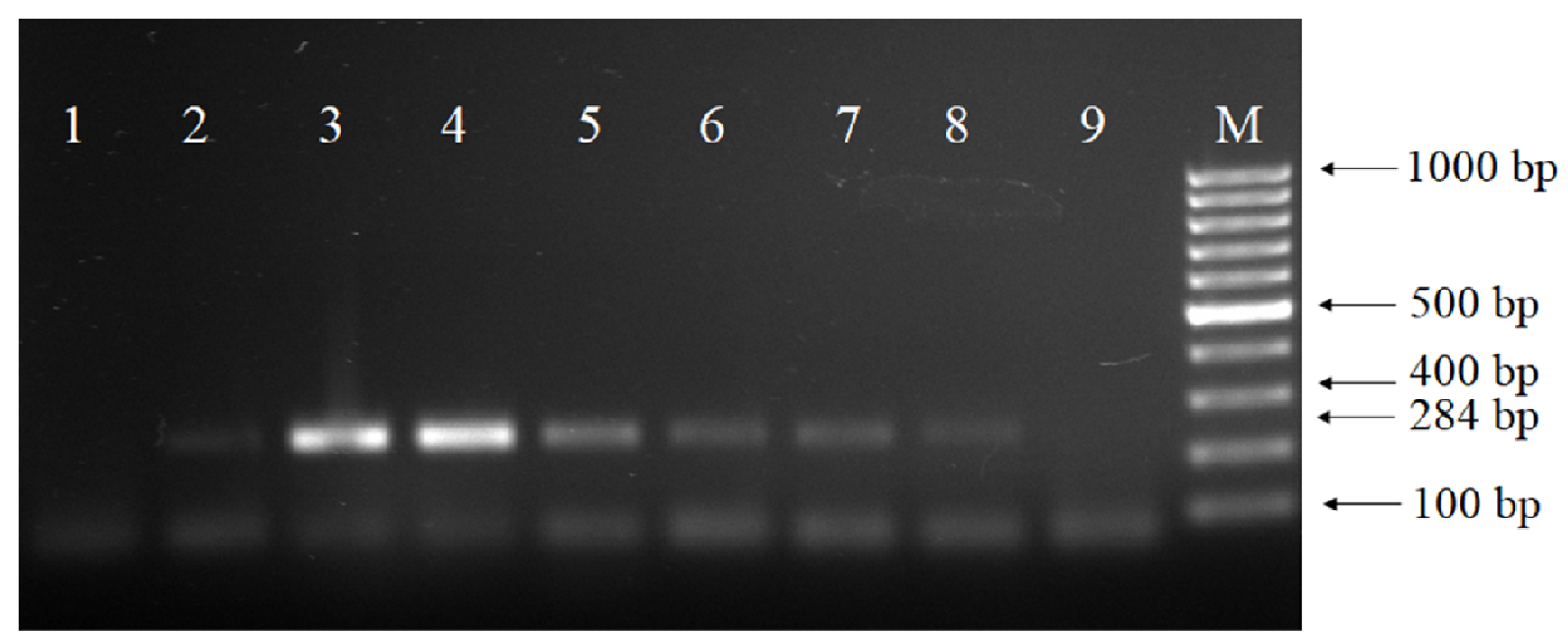

Figure 1. Detection of the invA (284 bp) gene by immunomagnetic separation-polymerase chain reaction. The samples were electrophoresed on a 1\% agarose gel. M: 1,000 bp marker; Lane 9: Negative control; Lane 8: Positive control (Salmonella typhimurium RSSK 95091; Lanes 2-7: Salmonella spp. positive samples; Lane 1: Salmonella spp. negative sample).

The antibiotic resistance and susceptibility of 30 Salmonella spp. isolates were determined using 10 different antibiotics (Table 3). As shown in Table 3, 27 of the 30 isolates showed the highest susceptibility to $\mathrm{CN}$, while all and 28 of the 30 isolates had the highest resistance to NA and TE, respectively. The highest susceptibility occurred in response to $\mathrm{CN}$, followed by $\mathrm{C}, \mathrm{AMP}, \mathrm{K}, \mathrm{SXT}, \mathrm{W}$, $\mathrm{S}, \mathrm{CIP}, \mathrm{TE}$ and NA, respectively. In contrast, the highest resistance was to NA and TE, followed by W, S, SXT, K, AMP, C, CIP and CN, respectively

Isolates that are resistant to three or more antibiotics are classified as multidrug resistant (MDR). It was determined that all [30 (100\%)] isolates were resistant to at least one antimicrobial agent, whereas $25(83.33 \%)$ were MDR. About $47 \%$ of the isolates showed resistance to five antibiotics, while $13.33 \%$ were resistant to six antibiotics. The distribution of antimicrobial resistance characteristics of the Salmonella spp. isolates is presented in Table 4. 
Table 3. Antibiotic susceptibility and resistance of obtained isolates (N:30).

\begin{tabular}{|c|c|c|c|c|c|c|}
\hline \multirow{2}{*}{ Antibiotics } & \multicolumn{2}{|c|}{ Susceptible } & \multicolumn{2}{|c|}{ Intermediate } & \multicolumn{2}{|c|}{ Resistant } \\
\hline & $\%$ & $\mathrm{~N}$ & $\%$ & $\mathrm{~N}$ & $\%$ & $\mathrm{~N}$ \\
\hline Streptomycin (S) & 6.67 & 2 & 23.33 & 7 & 70.00 & 21 \\
\hline Nalidixic acid (NA) & 0 & 0 & 0 & 0 & 100 & 30 \\
\hline Ciprofloxacin (CIP) & 3.33 & 1 & 90.00 & 27 & 6.67 & 2 \\
\hline Trimethoprim (W) & 20.00 & 6 & 6.67 & 2 & 73.33 & 22 \\
\hline Chloramphenicol (C) & 73.33 & 22 & 6.67 & 2 & 20.00 & 6 \\
\hline Gentamicin $(\mathrm{CN})$ & 90 & 27 & 6.67 & 2 & 3.33 & 1 \\
\hline $\begin{array}{l}\text { Trimethoprim/Sulfamethoxazole } \\
\text { (SXT) }\end{array}$ & 23.33 & 7 & 10.00 & 3 & 66.67 & 20 \\
\hline Ampicilin (AMP) & 66.67 & 20 & 6.67 & 2 & 26.67 & 8 \\
\hline Kanamycin (K) & 43.33 & 13 & 10.00 & 3 & 46.67 & 14 \\
\hline Tetracycline (TE) & 3.33 & 1 & 3.33 & 1 & 93.34 & 28 \\
\hline
\end{tabular}

Table 4. The distrubiton of antimicrobial resistance characteristics of Salmonella spp. isolates.

\begin{tabular}{lll}
\hline One type of antimicrobial & NA & $1(3.33 \%)$ \\
\hline Two types of antimicrobials & NA, TE & $3(10.00 \%)$ \\
& SXT, TE & $1(3.33 \%)$ \\
\hline Three types of antimicrobials & NA, SXT, TE & $1(3.33 \%)$ \\
& NA, W, TE & $1(3.33 \%)$ \\
\hline Four types of antimicrobials & NA, CIP, AMP, TE & $1(3.33 \%)$ \\
& NA, W, SXT, TE & $1(3.33 \%)$ \\
& NA, W, C, TE & $2(6.67 \%)$ \\
\hline Five types of antimicrobials & NA, W, SXT, TE & $1(3.33 \%)$ \\
& S, NA, W, AMP, K & $1(3.33 \%)$ \\
& S, NA, W, SXT, TE & $2(6.67 \%)$ \\
& NA, W, SXT, K, TE & $2(6.67 \%)$ \\
& NA, W, SXT, AMP, TE & $2(6.67 \%)$ \\
Nix types of antimicrobials & NA, C, AMP, K, TE & $6(20.00 \%)$ \\
\hline
\end{tabular}

\section{DISCUSSION}

The general microbiological quality parameters of the samples were determined with respect to TAMB, Pseudomonas, yeast and mould, coliform bacteria, Enterococcus and Staphylococcus/Micrococcus counts. According to the Food Standard, the presence of Salmonella spp., coliform and other bacteria are accepted as the hygiene index (ISO 2001, 2002). However, the results obtained here show that the samples did not meet the standards with respect to the presence of microorganisms. High numbers of bacteria shorten shelf life by deteriorating meat quality, resulting in an economic loss. Our results seem to be due to processing and storage conditions as well as crosscontamination after processing in the markets and homes.

The increase in food contamination factors and gastrointestinal diseases is associated with an increase in the risk of non-specific salmonellosis (CRUM-CIANFLONE, 2008). In Turkey and most developing countries, the absence of epidemiological studies of salmonellosis cases is an 
obstacle to effectively assess prevalence (KAFERSTEIN, 2003).

Our data corroborate previous studies revealing that chicken meat is an important food source contaminated by Salmonella spp. The difference in prevalence data for Salmonella spp. between previous studies and the present study might be due to sanitation conditions, methodological differences used to isolate the bacteria or transportation and storage conditions (LI et al., 2013). In this study, Salmonella spp. was detected in $41.67 \%$ of the chicken meat samples using the conventional method and $58.33 \%$ of the samples using the IMS-PCR technique. According to the Turkish Food Codex Communiqué on Microbiological Criteria, Salmonella spp. should not be found in any meat (TFC, 2011). Our results were lower than those reported previously (150/64, $42.66 \%$ ) by Siriken et al. (2015) in Ankara, Turkey. However, Yildirim et al. (2011) reported a 34\% (200/68) contamination rate by Salmonella in poultry meat in Turkey. The contamination rate of Salmonella in poultry meat varies among countries (ALVAREZ-FERNANDEZ et al., 2012). In the present study, the high prevalence rate of Salmonella in poultry meat was similar to the $60 \%$ reported in Portugal (ANTUNES et al., 2003) and $67.5 \%$ in Thailand (LERTWORAPREECHA et al., 2012), and was close to the contamination rates of $55 \%$ in Spain and 52.2\% in China (YANG et al., 2011). In contrast, the incidence rates of Salmonella in poultry meat in South Korea and Pakistan were $3.7 \%$ (RAN HEE et al., 2014) and 5.26\% (AKBAR; ANAL, 2013), respectively. These differences might be due to geographical location, bacteriological analytical methods, the sampling pattern or factors, such as hygiene and sanitation conditions during poultry meat production, crosscontamination or market conditions. Although the prevalence of Salmonella determined by the conventional method was close to or lower than that reported by many studies, it was possible to detect Salmonella using the IMS-PCR technique. All of these results indicate that poultry meat is an important source for Salmonella spp. infections.

The results show that the IMS-PCR technique was superior to the conventional method. The superiority of IMS-PCR over the conventional method might be due to the concentrations of the target microorganism in the samples, removal of inhibitor components or elimination of other microorganisms. Similar results were reported by Siriken et al. (2015) who detected Salmonella spp. in beef and poultry meat by both conventional and IMS methods. The IMS-PCR technique allows rapid detection of Salmonella spp. after IMS. Zheng et al. (2016) reported that IMS-PCR has an accuracy of $98.3 \%$.

The present study is significant because it is the first report that has detected the invA gene region of Salmonella in chicken meat. The PCR products of the isolates contained a PCR-positive control, which resulted in detection of a $284 \mathrm{bp}$ amplified fragment. The ability of Salmonellaspecific primers to detect Salmonella spp. rapidly and accurately was primarily due to the primer sequences selected from the invA gene. The invA protein in the inner membrane of Salmonella spp. is required for invasion of the bacterium into epithelial cells (SHARMA; DAS, 2016). All Salmonella spp. identified by conventional methods carry the invA gene region. Furthermore, this genus invades intestinal epithelial cells and the gene is found in pathogenic Salmonella spp. Therefore, it is important to identify the gene responsible for invasion. The invA gene is thought to trigger the internalisation necessary for invasion to deeper tissues, which is necessary for complete virulence of Salmonella spp. (LEI et al., 2015).

The resistance of bacteria to antibiotics has global importance in terms of failed zoonotic disease treatment. Antibiotic-resistant bacteria are important to public health, and their resistance genes are consumed with contaminated food or water (HONG et al., 2013). The most important source of antibiotic-resistant Salmonella spp. is animaloriginating foods. The data obtained from this study and other studies support these claims.

In this study, 10 different antibiotics were tested to determine antibiotic resistance of the isolates. Among the antibiotics, $\mathrm{CN}$ had the greatest effect on the isolates, followed by C, AMP, K, SXT, W, S, CIP, TE and NA. Cetinkaya et al. (2008) reported that Salmonella spp. was detectable in only one poultry meat sample in a study on the presence of Salmonella in different food samples (chicken parts, minced meat, ready-to-eat salad, raw vegetables and raw milk) sold in Bursa, Turkey. They identified the Salmonella spp. isolated as $S$. infantis and reported resistance to streptomycin, tetracycline, sulphonamides, trimethoprim, trimethoprim-sulphamethoxazole and NA. In another study, Kasimoglu Dogru et al. (2010) reported that $22(68.75 \%)$ of 32 strains isolated from poultry meat were resistant to multiple antibiotics. According to the same study, Salmonella spp. was most resistant to NA (62.5\%). Siriken et al. (2015) reported that Salmonella strains isolated from different meat samples are most resistant to vancomycin, tetracycline, streptomycin and NA. In 
the present study, the highest resistance of Salmonella spp. was to tetracycline and NA (100 and $93.34 \%$, respectively). In contrast, Arslan and Eyi (2010) reported that 50 of 225 meat samples were positive for Salmonella spp. These isolates had the highest resistance to ampicillin and cephazoline. It was also suggested that $62 \%$ of Salmonella strains have multiple resistance to tetracycline, carbenicillin, ampicillin and sulfamethoxazoletrimethoprim.

The high resistance to trimethoprime and sulfamethoxazole-trimethoprime was not surprising due to their continued use in human and veterinary clinics in Turkey. In addition, resistance to streptomycin was significantly higher than that reported in previous studies (LESTARI et al., 2009; MOLLA et al., 2003). Other studies have shown that resistance to streptomycin is due to its high prevalence and frequent use in veterinary medicine (MIHAIU et al., 2014). A higher resistance to streptomycin $(95 \%)$ was also reported by White et al. (2001) for Salmonella spp. isolated from chicken meat.

In the present study, Salmonella spp. isolated from chicken meat parts was highly resistant to NA (100\%). Our findings are consistent with studies conducted in different countries (CUI et al., 2016; SODAGARI et al., 2015) and in Turkey (KASIMOGLU DOGRU et al., 2010; SIRIKEN et al., 2015). In the past, ampicillin, chloramphenicol and co-trimoxazole were used to treat salmonellosis, but they have been replaced by fluoroquinolone antibiotics, such as ciprofloxacin and cephalosporin. After tetracycline, fluoroquinolones are the most widely used antibiotic group in veterinary medicine and are expected to become more resistant. NA resistance plays a role in the first steps of the development of ciprofloxacin resistance, although low resistance $(6.67 \%)$ of ciprofloxacin resistance is observed in the isolates. It should be emphasised that third-generation cephalosporins have recently become the primary drug to treat salmonellosis cases due to an increase in fluoroquinolone resistance (MAWATARI et al., 2013). For this reason, resistance to fluoroquinolones has emerged as an important public health issue because these antibiotics, which are widely used in veterinary medicine and poultry production, can cause resistance genes to be transmitted to humans through the food chain (GONZÁLEZ; ARAQUE, 2013).

In the present study, $26.67 \%$ of the isolates were resistant to ampicillin, which was remarkably lower than the resistance reported in other countries by Thung et al. (2016) in Malaysia (72.73\%), Trongjit et al. (2017) in Thailand (72.4\%) and Yen et al. (2014) in Vietnam (41.6\%). It is not surprising that ampicillin is still preferred in the classical treatment of salmonellosis in humans and it is not often used in animal therapy in Turkey.

According to a report published by EFSA in 2014 (EFSA, 2014), Salmonella spp. isolates of broiler origin in 22 different European Union countries were reported to have the highest resistance to NA (48.7\%), sulfamethoxazole $(45.1 \%)$ and tetracycline $(40.4 \%)$. Although the results obtained in our study excluding resistance to trimethoprim were qualitatively similar, resistance rates were determined to be higher in our study. However, these results are similar to those obtained from countries, such as Bulgaria and Hungary, as they reflect the average of the data of 22 different member countries. The low level of resistance to gentamicin $(6.6 \%)$ was close to our study results $(4.76 \%)$. In the same report, resistance to chloramphenicol was lower (4\%), although it was high in the present study (26.98\%).

\section{CONCLUSIONS}

The results showed that 30 of the 72 samples were positive for Salmonella spp. by the conventional method, while 42 of the 72 were positive by IMS-PCR. In contrast, 30 of the 72 samples were positive by both methods. In conclusion, combining the IMS and PCR methods was used effectively to isolate Salmonella from chicken than either method alone.

The 30 identified Salmonella spp. isolates were evaluated in terms of antibiotic resistance and susceptibility. The results indicated that the highest resistance was to NA and TE, while the highest susceptibility was to GN. Taken together, it is evident that chicken meat is a serious public health risk in this region in terms of the presence of Salmonella spp. in chicken meat parts, antibiotic resistance of isolates and microbiological properties of chicken meat parts.

RESUMO: Parâmetros microbiológicos específicos e a presença de Salmonella spp. foram investigados em 72 amostras de carne de frango (36 asas e 36 baquetas) coletadas em mercados e açougues. Os parâmetros microbiológicos específicos foram determinados utilizando um método cultural convencional e a presença de Salmonella spp. em amostras de frango foi determinada utilizando métodos de reação em cadeia da 
polimerase (PCR) por separação convencional e imunomagnética (IMS). Além disso, a suscetibilidade antimicrobiana dos isolados foi revelada pelo método de difusão do disco de Kirby-Bauer. Os resultados indicaram que 30 das 72 amostras foram positivas para Salmonella spp. pelo método convencional, e 42 das 72 foram positivas pelo método IMS-PCR. No entanto, 30 das 72 amostras foram positivas para Salmonella spp. por ambos os métodos. Os isolados de Salmonella spp. foram confirmados pelo sistema VITEK2 Compact e PCR. As susceptibilidades dos isolados a 10 antibióticos foram determinadas. Os resultados indicaram que os isolados (27/30) apresentaram maior suscetibilidade à gentamicina $(90,00 \%)$, enquanto a maior resistência foi ao ácido nalidíxico e à tetraciclina nos níveis de 100 e 93,34\%, respectivamente. Estes resultados indicam uma alta prevalência de Salmonella spp. em carne de frango da cidade de Erzurum, Turquia, e o perfil de resistência antimicrobiana desses isolados deve ser considerado para a saúde pública. Os resultados também demonstram que a técnica de IMS-PCR foi superior ao método convencional para detecção de Salmonella em carne de frango.

PALAVRAS-CHAVE: Carne de frango. Salmonella. IMS. PCR. Antimicrobiano.

\section{REFERENCES}

AKBAR, A.; ANAL, A. K. Prevalence and antibiogram study of Salmonella and Staphylococcus aureus in poultry meat. Asian Pacific Journal of Tropical Biomedicine, v. 3, n. 2, p. 163-168, 2013.

https://dx.doi.org/10.1016\%2FS2221-1691(13)60043-X.

Alvarez-Fernandez, E.; Alonso-Calleja, C.; Garcia-Fernandez, C.; Capita, R. Prevalence and antimicrobial resistance of Salmonella serotypes isolated from poultry in Spain: comparison between 1993 and 2006.

International Journal of Food Microbiology, v. 153, n. 3, p. 281-287, 2012.

https://doi.org/10.1016/j.ijfoodmicro.2011.11.011.

ANTUNES, P. C.; RÉU, C.; SOUSA, J. C.; PEIXE, L. S.; PESTANA, N. Incidence of Salmonella from poultry products and their susceptibility to antimicrobial agents. International Journal of Food Microbiology, v. 82, n. 2, p. 97-103, 2003. https://doi.org/10.1016/S0168-1605(02)00251-9.

Arslan, S.; Eyi, A. Occurrence and antimicrobial resistance profiles of Salmonella species in retail meat products. Journal of Food Protection, v. 73, n. 9, p. 1613-1617, 2010. https://doi.org/10.4315/0362-028X73.9.1613.

BENNETT, A.; GREENWOOD, D.; TENNANT, C.; BANKS, J.; BETTS, R. Rapid and definitive detection of Salmonella in foods by PCR. Letters in Applied Microbiology, v. 26, n. 6, p. 437-441, 1998. https://doi.org/10.1046/j.1472-765X.1998.00368.x.

BYWATER, R. Veterinary use of antimicrobials and emergence of resistance in zoonotic and sentinel bacteria in the EU. Zoonoses and Public Health, v. 51, n. 8-9, p. 361-363, 2004. https://doi.org/10.1111/j.14390450.2004.00791.x.

CDC. Centers For Disease Control And Prevention. Snapshots of Salmonella Serotypes. In: < https://www.cdc.gov/salmonella/reportspubs/salmonella-atlas/serotype-snapshots.html.>; Accessed on: March $5,2018$.

CETINKAYA, F.; CIBIK, R.; SOYUTEMIZ, G. E.; OZAKIN, C.; KAYALI, R.; LEVENT, B. Shigella and Salmonella contamination in various foodstuffs in Turkey. Food Control, v. 19, n. 11, p. 1059-1063, 2008. https://doi.org/10.1016/j.foodcont.2007.11.004.

CLSI. Clinical and Laboratory Standards Institute. Performance Standards for Antimicrobial Disk Susceptibility Tests, Approved Standard M2-A9. Wayne, PAClinical and Laboratory Standards Institute. 2006. 
CRUM-CIANFLONE, N. F. Salmonellosis and the gastrointestinal tract: more than just peanut butter. Current Gastroenterology Reports, v. 10, n. 4, p. 424-431, 2008. https://doi.org/10.1007/s11894-008-0079-7.

CUI, M.; XIE, M.; QU, Z.; ZHAO, S.; WANG, J.; WANG, Y.; HE, T.; WANG, H.; ZUO, Z.; WU, C. Prevalence and antimicrobial resistance of Salmonella isolated from an integrated broiler chicken supply chain in Qingdao, China. Food control, v. 62, n. p. 270-276, 2016. https://doi.org/10.1016/j.foodcont.2015.10.036.

Dookeran, M.; Baccus-Taylor, G.; Akingbala, J.; Tameru, B.; Lammerding, A. Transmission of Salmonella on broiler chickens and carcasses from production to retail in Trinidad and Tobago. Journal of Agricultural Biodiversity Research, v. 1, n. 5, p. 78-84, 2012.

EFSA. The European Union Summary Report on antimicrobial resistance in zoonotic and indicator bacteria from humans, animals and food in 2012. EFSA Journal, v. 12, n. 3, p. 1-22, 2014. https://doi.org/10.2903/j.efsa.2014.3590.

GONZÁLEZ, F.; ARAQUE, M. Association of Transferable Quinolone Resistance Determinant qnrB19 with Extended-Spectrum $\beta$-Lactamases in Salmonella Give and Salmonella Heidelberg in Venezuela. International Journal of Food Microbiology, v. 2013, n. p. 628185, 2013. http://dx.doi.org/10.1155/2013/628185

HAGREN, V.; VON LODE, P.; SYRJÄLÄ, A.; KORPIMÄKI, T.; TUOMOLA, M.; KAUKO, O.; NURMI, J. An 8-hour system for salmonella detection with immunomagnetic separation and homogeneous time-resolved fluorescence pcr. International journal of food microbiology, v. 125, n. 2, p. 158-161, 2008.

https://doi.org/10.1016/j.ijfoodmicro.2008.03.037.

HASSANEIN, R.; ALI, S. F. H.; EL-MALEK, A.; MOHAMED, A.; MOHAMED, M. A.; ELSAYH, K. I. Detection and identification of Salmonella species in minced beef and chicken meats by using Multiplex PCR in Assiut city. Veterinary World, v. 4, n. 1, p. 5-11, 2011. 1 https://doi.org/10.5455/vetworld.2011.5-11.

HONG, P. Y.; AL-JASSIM, N.; ANSARI, M.; MACKIE, R. Environmental and Public Health implications of water reuse: antibiotics, antibiotic resistant bacteria, and antibiotic resistance genes. Antibiotics, v. 2, n. 3, p. 367, 2013. https://dx.doi.org/10.3390\%2Fantibiotics2030367.

ISO. International Organization for Standardization. Microbiology of food and animal feeding stuffs Horizontal method for the detection of Escherichia coli O157. 1. ed. USA. 2001.

ISO. International Organization for Standardization. Microbiology of food and animal feeding stuffs Horizontal method for the detection of Salmonella spp. 1. ed. USA. 2002.

JEONG, E. S.; LEE, K. S.; HEO, S. H.; SEO, J. H.; CHOI, Y. K. Triplex PCR for the Simultaneous Detection of Pseudomonas aeruginosa, Helicobacter hepaticus, and Salmonella typhimurium. Experimental Animals, v. 60, n. 1, p. 65-70, 2011. https://doi.org/10.1538/expanim.60.65.

KAFERSTEIN, F. Foodborne diseases in developing countries: aetiology, epidemiology and strategies for prevention. International Journal of Environmental Health Research, v. 13, Suppl. 1, p. 161-168, 2003. https://doi.org/10.1080/0960312031000102949.

KÄFERSTEIN, F. Actions to reverse the upward curve of foodborne illness. Food Control, v. 14, n. 2, p. 101109, 2003. https://doi.org/10.1016/S0956-7135(02)00017-8.

KASIMOGLU DOGRU, A.; AYAZ, N. D.; GENCAY, Y. E. Serotype identification and antimicrobial resistance profiles of Salmonella spp. isolated from chicken carcasses. Tropical Animal Health and Production, v. 42, n. 5, p. 893-897, 2010. https://doi.org/10.1007/s11250-009-9504-7. 
LEI, P.; TANG, H.; DING, S.; DING, X.; ZHU, D.; SHEN, B.; CHENG, Q.; YAN, Y. Determination of the invA gene of Salmonella using surface plasmon resonance along with streptavidin aptamer amplification. Microchimica Acta, v. 182, n. 1, p. 289-296, 2015. https://doi.org/10.1007/s00604-014-1330-6.

LERTWORAPREECHA, M.; SUTTHIMUSIK, S.; TONTIKAPONG, K. Antimicrobial resistance in Salmonella enterica isolated from pork, chicken, and vegetables in southern Thailand. Jundishapur Journal of Microbiology, v. 6, n. 1, p. 36-41, 2012. http://dx.doi.org/10.5812/jjm.4312.

LESTARI, S. I.; HAN, F.; WANG, F.; GE, B. Prevalence and antimicrobial resistance of Salmonella serovars in conventional and organic chickens from Louisiana retail stores. Journal of Food Protection, v. 72, n. 6, p. 1165-1172, 2009. https://doi.org/10.4315/0362-028X-72.6.1165.

LI, R.; LAI, J.; WANG, Y.; LIU, S.; LI, Y.; LIU, K.; SHEN, J.; WU, C. Prevalence and characterization of Salmonella species isolated from pigs, ducks and chickens in Sichuan Province, China. International Journal of Food Microbiology, v. 163, n. 1, p. 14-18, 2013. https://doi.org/10.1016/j.ijfoodmicro.2013.01.020.

Lynch, M. J.; Leon-Velarde, C. G.; McEwen, S.; Odumeru, J. A. Evaluation of an automated immunomagnetic separation method for the rapid detection of Salmonella species in poultry environmental samples. Journal of Microbiological Methods, v. 58, n. 2, p. 285-288, 2004. https://dx.doi.org/10.3390\%2Fijerph110909811.

MAWATARI, M.; KATO, Y., HAYAKAWA, K.; MORITA, M.; YAMADA, K.; MEZAKI, K.; KOBAYASHI, T.; FUJIYA, Y.; KUTSUNA, S.; TAKESHITA, N.; KANAGAWA, S.; OHNISHI, M.; IZUMIYA, H.; OHMAGARI, N. Salmonella enterica serotype Paratyphi A carrying CTX-M-15 type extendedspectrum beta-lactamase isolated from a Japanese traveller returning from India, Japan, July 2013. Euro Surveillance, v. 18, n. 46, p. 20632, 2013. https://doi.org/10.2807/1560-7917.ES2013.18.46.20632.

MIHAIU, L.; LAPUSAN, A.; TANASUICA, R.; SOBOLU, R.; MIHAIU, R.; ONIGA, O.; MIHAIU, M. First study of Salmonella in meat in Romania. The Journal of Infection in Developing Countries, v. 8, n. 01, p. 050-058, 2014. https://doi.org/10.3855/jidc.3715.

MOGANEDI, K.; GOYVAERTS, E.; VENTER, S. N.; SIBARA, M. Optimisation of the PCR-invA primers for the detection of Salmonella in drinking and surface waters following a pre-cultivation step. Water Sa, v. 33, n. 2, p. 195-202, 2007. https://doi.org/10.4314/wsa.v33i2.49060.

MOLLA, B.; MESFIN, A.; ALEMAYEHU, D. Multiple antimicrobial-resistant Salmonella serotypes isolated from chicken carcass and giblets in Debre Zeit and Addis Ababa, Ethiopia. Ethiopian Journal of Health Development, v. 17, n. 2, p. 131-139, 2003. http://dx.doi.org/10.4314/ejhd.v17i2.9854.

RAN HEE, Y.; SE YEOUN, C.; BAI, W.; JAE HEE, R.; HYE SUK, S.; JAE YOUNG, O.; HYUNG KWAN, J. Prevalence of Salmonella isolates and antimicrobial resistance in poultry meat from South Korea. Journal of Food Protection, v. 77, n. 9, p. 1579-1582, 2014. https://doi.org/10.4315/0362-028X.JFP-14-018.

SCHEU, P. M.; BERGHOF, K.; STAHL, U. Detection of pathogenic and spoilage micro-organisms in food with the polymerase chain reaction. Food Microbiology, v. 15, n. 1, p. 13-31, 1998.

https://doi.org/10.1006/fmic.1997.0134.

SHARMA, I.; DAS, K. Detection of invA gene in isolated Salmonella from marketed poultry meat by PCR assay. Journal of Food Processing Technology, v. 7, n. 564, p. 2-4, 2016. https://doi.org/10.4172/21577110.1000564 .

SIRIKEN, B.; TÜRK, H.; YILDIRIM, T.; DURUPINAR, B.; EROL, I. Prevalence and characterization of Salmonella isolated from chicken meat in Turkey. Journal of Food Science, v. 80, n. 5, p. 2015. https://doi.org/10.1111/1750-3841.12829. 
SODAGARI, H. R.; MASHAK, Z.; GHADIMIANAZAR, A. Prevalence and antimicrobial resistance of Salmonella serotypes isolated from retail chicken meat and giblets in Iran. Journal of Infection in Developing Countries, v. 9, n. 5, p. 463-469, 2015. https://doi.org/10.3855/jidc.5945.

TABAN, B. M.; AYTAC, S. A. Application of magnetic immuno-polymerase chain reaction assay for detection of Salmonella spp. in chicken meats. European Food Research and Technology, v. 229, n. 4, p. 623-628, 2009. https://doi.org/10.1007/s00217-009-1091-3.

TEUBER, M. Veterinary use and antibiotic resistance. Current Opinion in Microbiology, v. 4, n. 5, p. 493499, 2001. https://doi.org/10.1016/S1369-5274(00)00241-1.

TFC. Turkısh Food Codex. Türk Gıda Kodeksi Mikrobiyolojik Kriterler Yönetmeliği. Ankara, Turkey. 2011.

THSK. Turkish Public Health Institution. Salmonella Enfeksiyonları. p. 5-6. Ankara, Turkey. 2015.

THUNG, T. Y.; MAHYUDIN, N. A.; BASRI, D. F.; WAN MOHAMED RADZI, C. W. J.; NAKAGUCHI, Y.; NISHIBUCHI, M.; RADU, S. Prevalence and antibiotic resistance of Salmonella Enteritidis and Salmonella Typhimurium in raw chicken meat at retail markets in Malaysia. Poultry Science, v. 95, n. 8, p. 1888-1893, 2016. https://doi.org/10.3382/ps/pew144.

TRONGJIT, S.; ANGKITITRAKUL, S.; TUTTLE, R. E.; POUNGSEREE, J.; PADUNGTOD, P.;

CHUANCHUEN, R. Prevalence and antimicrobial resistance in Salmonella enterica isolated from broiler chickens, pigs and meat products in Thailand-Cambodia border provinces. Microbiology and Immunology, v. 61, n. 1, p. 23-33, 2017. https://doi.org/10.1111/1348-0421.12462.

TSE. Turkish Standardization Institute. Meat and meat products (red meats) methods of laboratory analysis. Ankara, Turkey. 2016.

VOSE, D.; KOUPEEV, T.; MINTIENS, K. A quantitative microbiological risk assessment of Salmonella spp. in broiler (Gallus gallus) meat production. EFSA Supporting Publications, v. 8, n. 7, p. 1-81, 2011. https://doi.org/10.2903/sp.efsa.2011.EN-183.

WHITE, D. G.; ZHAO, S.; SUDLER, R.; AYERS, S.; FRIEDMAN, S.; CHEN, S.; MCDERMOTT, P. F.; MCDERMOTT, S.; WAGNER, D. D.; MENG, J. The isolation of antibiotic-resistant Salmonella from retail ground meats. The New England Journal of Medicine, v. 345, n. 16, p. 1147-1154, 2001.

https://doi.org/10.1056/NEJMoa010315.

YANG, Z. Y., SHIM, W. B., KIM, K. Y., CHUNG, D. H. Rapid detection of Enterotoxigenic Clostridium perfringens in meat samples using immunomagnetic separation Polymerase Chain Reaction (IMS- PCR).

Journal of Agricultural and Food Chemistry, v. 58, n. 12, p. 7135-7140, 2010.

https://doi.org/10.1021/jf1009654.

YANG, B.; XI, M.; WANG, X.; CUI, S.; YUE, T.; HAO, H.; WANG, Y.; CUI, Y.; ALALI, W.; MENG, J. Prevalence of Salmonella on raw poultry at retail markets in China. Journal of Food Protection, v. 74, n. 10, p. 1724-1728, 2011. https://doi.org/10.4315/0362-028X.JFP-11-215.

TA, Y. T.; NGUYEN, T. T.; TO, P. B.; PHAM DA, X.; LE, H. T.; THI, G. N.; ALALI, W. Q.; WALLS, I.; DOYLE, M. P. Quantification, serovars, and antibiotic resistance of Salmonella isolated from retail raw chicken meat in Vietnam. Journal of Food Protection, v. 77, n. 1, p. 57-66, 2014.

https://doi.org/10.4315/0362-028x.Jfp-13-221

YILDIRIM, Y.; GONULALAN, Z.; PAMUK, S.; ERTAS, N. Incidence and antibiotic resistance of Salmonella spp. on raw chicken carcasses. Food Research International, v. 44, n. 3, p. 725-728, 2011.

https://doi.org/10.1016/j.foodres.2010.12.040. 
ZHENG, Q.; MIKŠ-KRAJNIK, M.; YANG, Y.; LEE, S. M.; LEE, S. C.; YUK, H. G. Evaluation of real-time PCR coupled with immunomagnetic separation or centrifugation for the detection of healthy and sanitizerinjured Salmonella spp. on mung bean sprouts. International Journal of Food Microbiology, v. 222, n. 2, p. 48-55, 2016. https://doi.org/10.1016/j.jifoodmicro.2016.01.013. 